\title{
Late Medieval Magistrate's Sword from the Collections of Buchlov State Castle
}

\author{
Późnośredniowieczny miecz magistracki z kolekcji Zamku Buchlov
}

\begin{abstract}
The collections of Buchlov State Casthe $16^{\text {th }}$ century in Passau, Bavaria. This article tle include, among other things, a richly decorated late medieval long-sword that can be, based on its overall character, including maker's marks on its blade, reliably interpreted as a so-called magistrate's sword made around the turn of discusses the nature of its decoration in comparison with other similar preserved Central European magistrates' swords of Passau provenance, as well as both the practical and symbolic function of these weapons.
\end{abstract}

Keywords: magistrate's sword, Passau, molten-metal inlay, wire inlay, Late Middle Ages

The collections of Buchlov State Castle contain a large number of interesting objects that can mostly be connected with the former family museum of the last private owners of the castle, the Counts of Berchtold. In addition to rich scientific, ethnographic and Egyptological collections, the museum was over time also supplemented with various curiosities. Last but not least, the museum also included a collection of objects of a military character, at the time very popular and through which the $17^{\text {th }}$ - to $19^{\text {th }}$-century nobility programmatically claimed their ancestral legacy and hence referred to the military tradition of the nobility and its social supremacy in general (e.g., Prchal 20I5). Armouries and collections of weapons held at residences of the modern period aristocracy thus became an important aspect of its strategy for self-presentation and, therefore, as early as the $18^{\text {th }}$ century, a lively trade in old weapons can be observed throughout Europe. Therefore, it is 
sometimes difficult, in many cases in fact even impossible - especially if we lack the then related inventories - to distinguish between old weapons stored in such collections as items belonging to the original equipment and those purchased at the time of establishing 'artificial' representative armouries. Unfortunately, old inventories of the collection of weapons held at Buchlov Castle are missing as well.

Although the collection of arms and armour at Buchlov is not an extensive one, it contains a number of very interesting objects. One of them is undoubtedly the richly decorated sword from the turn of the $16^{\text {th }}$ century, to which this short study is dedicated ${ }^{1}$. Unfortunately, we lack any information about how this weapon was obtained for the collection. In the older literature devoted to the history of the castle, we read that one sword was stored in the collections - a weapon allegedly found together with a spur close to nearby Hradčovice (Dolejšek I893: 14); however, this information probably concerns a long-sword held in the collections today but for which the museum records state, probably incorrectly, that it was found in the surroundings of the town of Strážnice (Procházka 1999: 577, cat. no. 294; Žákovský et al. 2017: 164, fig. 17:e; Hošek et al. 2019: cat. ID No 23I). It is not even clear whether the weapon could have been mentioned by older authors among the swords traditionally associated with the performance of the famous Buchlov hunting court functioning probably since the $14^{\text {th }}$ century, although we consider this possibility very probable (Dolejšek I893: I8).

\section{Description of the sword and its decoration}

The weapon is a fully intact long-sword with a total length of I2 $45 \mathrm{~mm}$ and a weight of $222 \mathrm{I}$ g, with the centre of gravity situated roughly $80 \mathrm{~mm}$ below the lower edge of a crossguard. Its $935 \mathrm{~mm}$-long blade is provided on both sides with a relatively wide but rather indistinctly outlined fuller running approximately halfway down the blade length. The blade is $54 \mathrm{~mm}$ wide under the crossguard and only slightly and parabolically tapers towards the indistinctly rounded point. By contrast, the blade thickness narrows gradually from 6 to i $\mathrm{mm}$ towards the point. Both surfaces, especially the 'weak' part of the blade, bear traces of imperfect welding indicating that the processing of the used material cannot be considered ideal, which is further supported by more pronounced damage observed at the pointed part. These traces in the form of longitudinal scars are observable on the blade when using $\mathrm{x}$-ray radiography ${ }^{2}$ and in many places even with the naked eye. It seems that the

\footnotetext{
1 National Heritage Institute - Buchlov State Castle, inv. No. BU 959/290.

2 X-ray radiography was performed using a stationary X-ray source $\mathrm{I} 203$ ( $120 \mathrm{kV} / 36 \mathrm{~W}$, focus $5 \mu \mathrm{m})$ and a digital detector $(400 \times 400 \mathrm{~mm}, 2048 \times 2048$ pixels with a size of $0.2 \mathrm{~mm})$.
} 


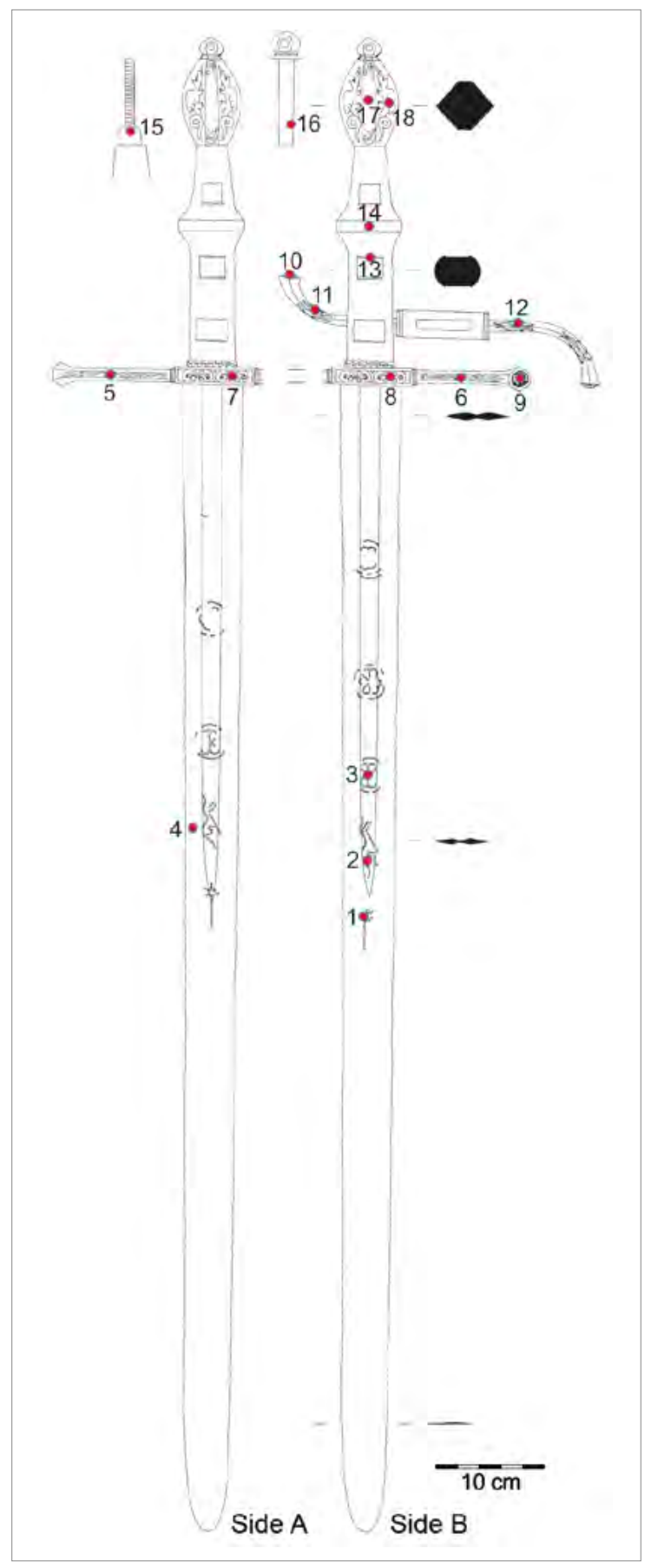

Fig. 1. Drawing of the sword with the designated areas in which elemental composition was measured (numbering of the areas corresponds to the numbering of the measurements in Table I). Drawing by P.Žákovský, P. Bárta and M. Kmošek. 


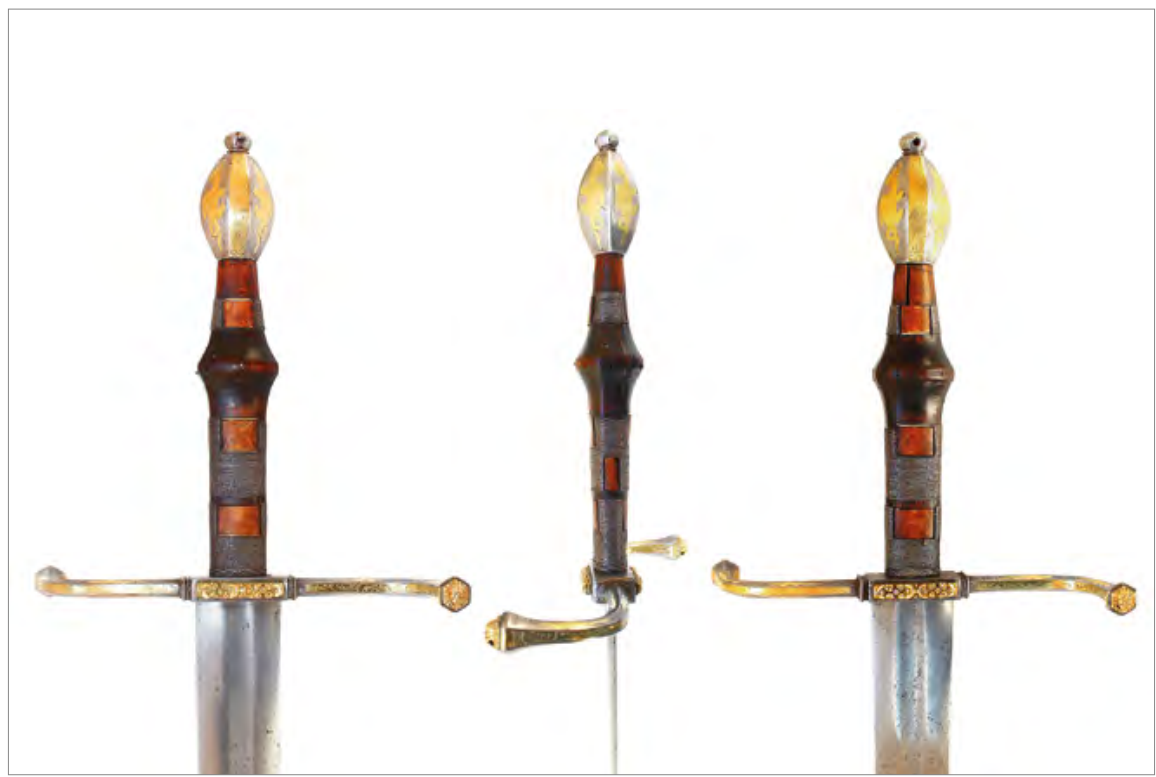

Fig. 2. The hilt of the sword. Photo by P.Žákovský.

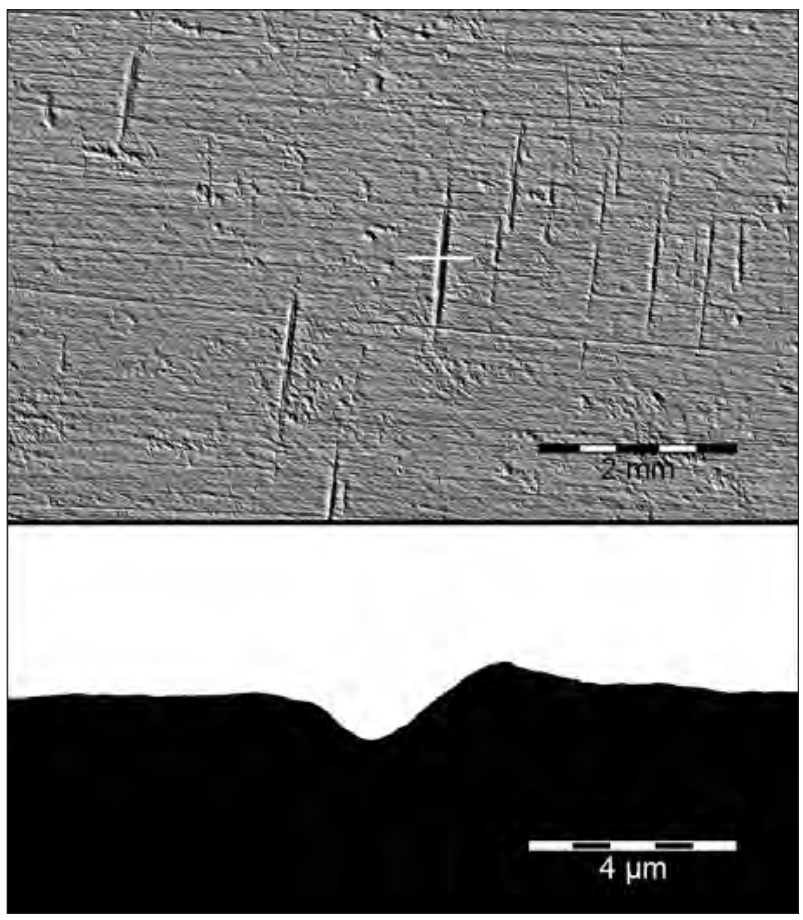

Fig. 3.

Traces of grinding on the blade surface near the point and a virtual cross-section through one of the grooves. Photo by M. Kmošek. 

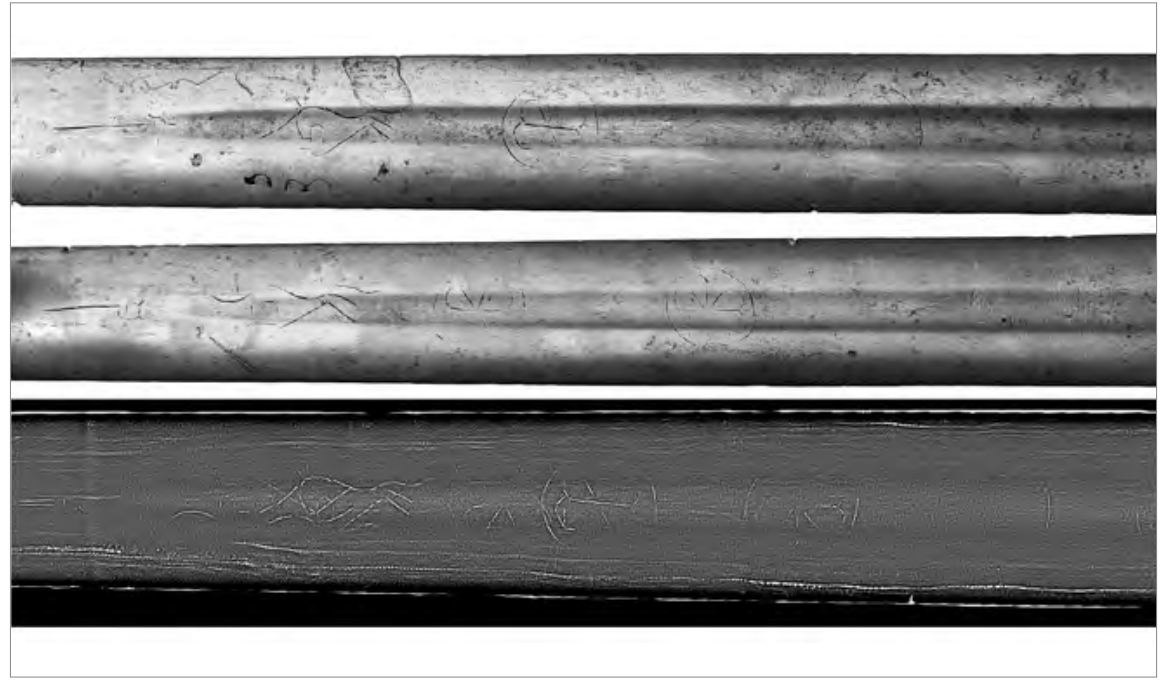

Fig.4. Section of the blade with maker's marks and corresponding x-ray image revealing also welding lines. Photo by P. Žákovský.

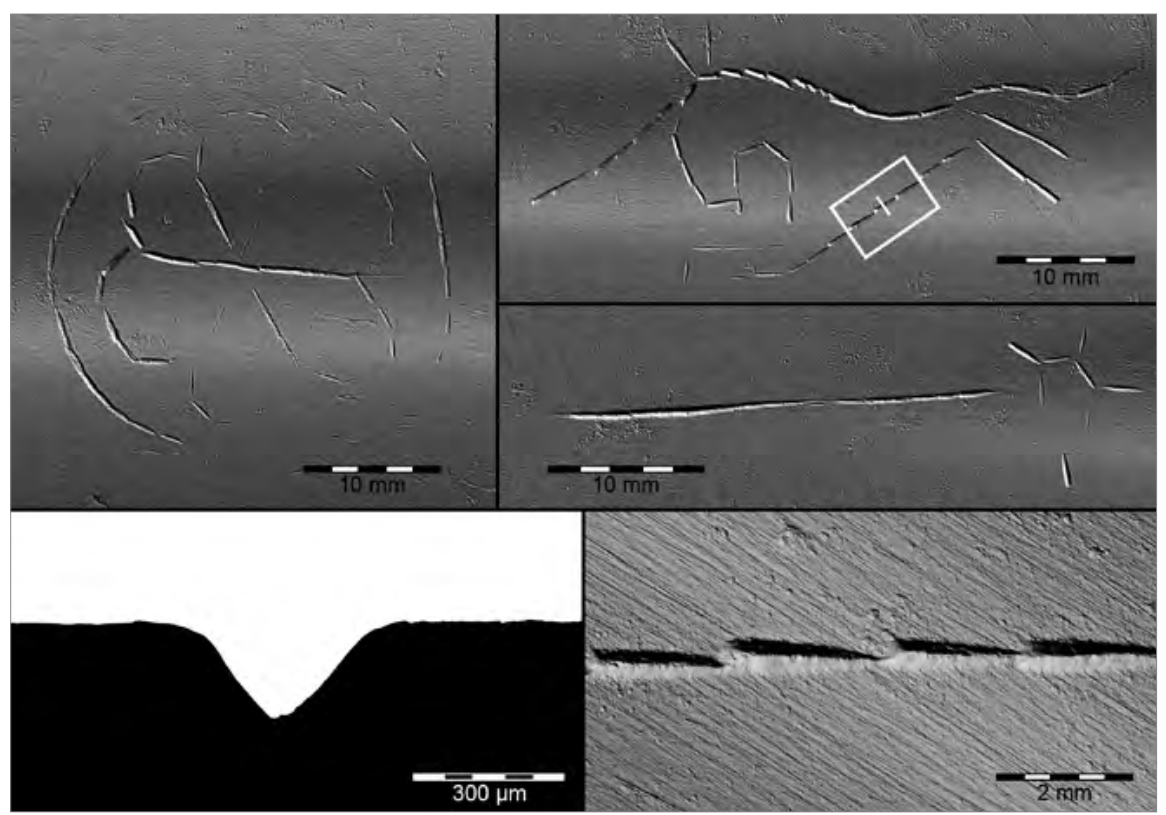

Fig. 5. Details of the maker's marks on the blade, including a virutal cross-section through one of the grooves. Photo by M. Kmošek. 


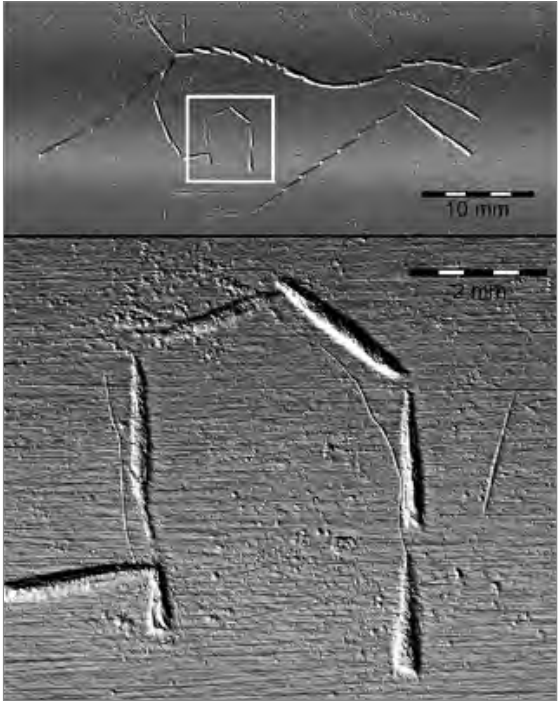

Fig.6. Fine lines running parallel to the chisel-punched grooves and hence suggesting that the craftsman pre-drew the mark (in this case taking the form of a unicorn) with a needle. Photo by M. Kmošek.

planes of all welds run more-or-less parallel to the edge-to-edge plane, i.e., there are presumably no welds running crosswise from surface to surface. This means that there are no visible traces that would indicate welded-on cutting edges. Hypothetically, it is possible to consider either an all-steel blade or a blade with a softer core surrounded by a jacket of steel. However, accurate determination of the blade construction is impossible without metallographic examination. On both blade surfaces, one can also visually observe small parallel shallow grooves running either perpendicularly, obliquely or longitudinally to the blade axis, and which can reliably be considered traces of grinding the blade using a grinding stone ${ }^{3}$. The material extruded on one side of the grooves by the pressure induced by grinding indicates the low surface hardness of the blade, which is also evidenced by macroscopically visible deformations of cutting edges in the places of notches.

The fullers on both sides of the 'strong' part of the blade bear relatively distinctive and large maker's marks (Fig. 4). On one of the sides, we see a trio of six-petalled rosettes in a circle, a leftward running unicorn and a bishop's crosier. The other side bears the same marks, and the only difference is that the rosettes differ from each other and the one situated closest to the crossguard is heavily worn or ground off. The lines of marks are formed by grooves with a v-shaped profile created by a single chisel punch with a roughly $2 \mathrm{~mm}$-long straight and rather blunt blade. The long groves of the individual signatures were created by chaining individual prints made by the punch, often without consistently maintaining the smooth shape of the lines, especially when being curved. Besides the chisel-punched grooves, fine lines are also visible running parallel to the grooves and hence roughly following the existing shape of a mark. These are most likely remnants of pre-drawing the

3 Microscopic examination and documentation were performed using the LMI ToolScan forensic examination system ( $2 \mathrm{D}$ and $3 \mathrm{D}$ scanning of the surface, $\mathrm{BW}$ camera, $3 \mu \mathrm{m} / \mathrm{px}$ resolution, reconstruction of the surface by EDF and photometric stereo). 


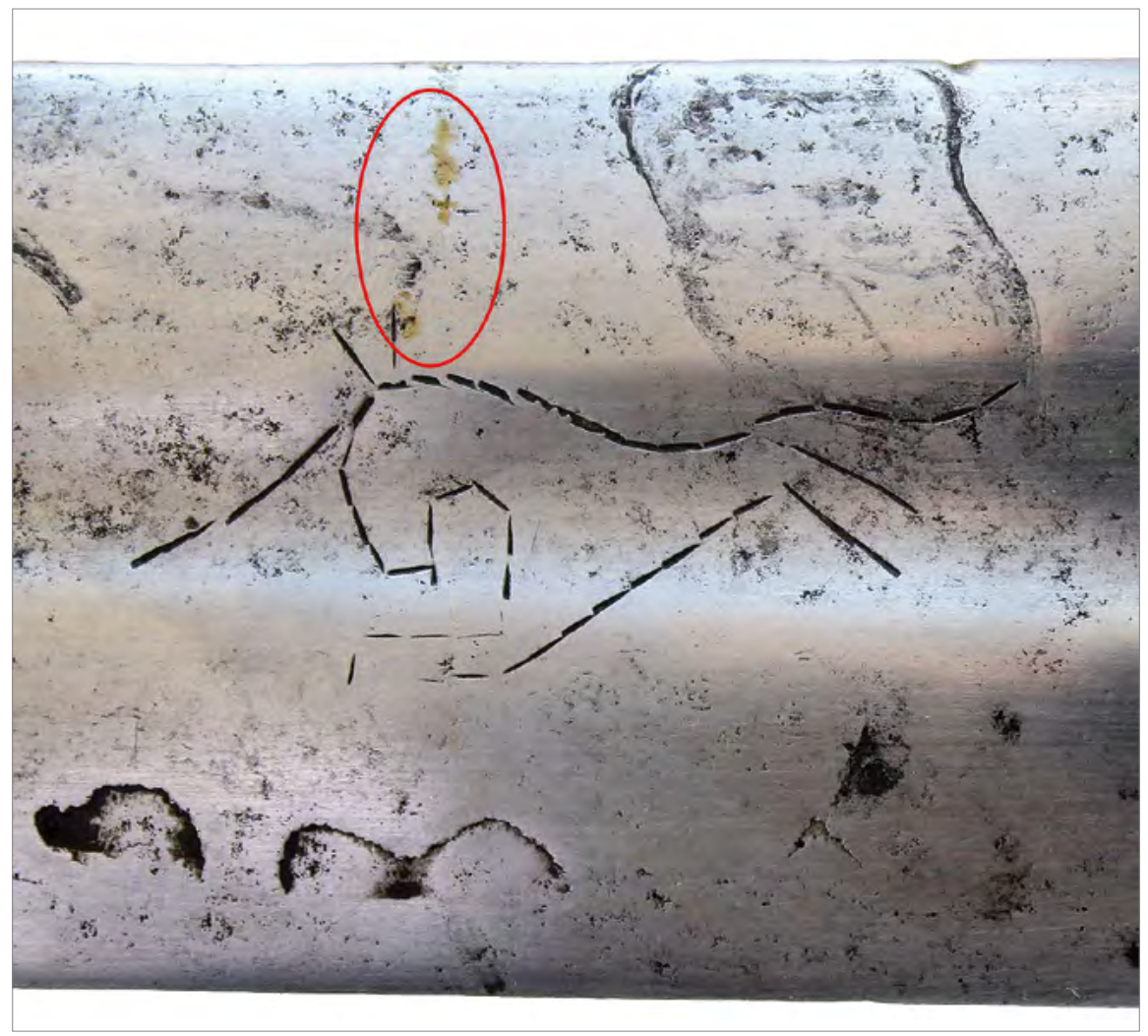

Fig.7. Traces of brass that accidentally filled depressions not associated with any maker's mark. Photo by P. Žákovský.

mark's outline by a needle before the grooves forming the mark itself were made. Some of the chisel-punched grooves are inlaid with brass ${ }^{4}$ with approximately $20 \% \mathrm{Zn}$. It is undoubtedly a molten-metal inlay because a V-shaped profile of the

4 The elemental composition was determined using a Niton XL3t 980 handheld XRF spectrometer ( $\mathrm{Rh}$ anode, General metals mode, measurement time 20-30 seconds, the diameter of the measured area 3 or $8 \mathrm{~mm}$, acceleration voltage $50 \mathrm{kV}$ ). The surface character of the measurements must be taken into account when evaluating and interpreting the obtained data. The analysed area was partially altered by corrosion processes and contaminated with dust particles and protective coatings. Due to the limited possibilities to measure small areas and often the small size of the examined non-ferrous components/ inlays, the surrounding iron matrix is often noticeably reflected in the results. Taking into account the above, the obtained data should be perceived as qualitative and at best semi-quantitative. In order to give the reader a better idea of the composition of the analysed components/inlays, the Table with the results also contains the conversion of the composition to $100 \%$ of $\mathrm{Cu}-\mathrm{Zn}$. The location of the analysed areas is shown in Fig. I. 
Tab.1. Results of elemental composition analyses of individual non-ferrous maker's marks, grip components and parts of decoration (positions of individual analyses are depicted in Fig. I).

\begin{tabular}{|c|c|c|c|c|c|c|c|c|c|c|c|c|c|}
\hline \multirow{2}{*}{ 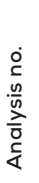 } & \multirow{2}{*}{ 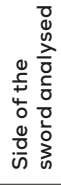 } & \multirow{2}{*}{ 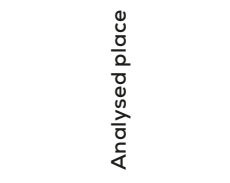 } & \multirow{2}{*}{ 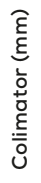 } & \multicolumn{8}{|c|}{ Elemental composition (wt\%) } & \multicolumn{2}{|c|}{$\begin{array}{l}\text { Conversion } \\
\text { to } 100 \% \text { CuZn }\end{array}$} \\
\hline & & & & $\mathrm{Fe}$ & $\mathrm{Cu}$ & $\mathrm{Zn}$ & $\mathrm{Au}$ & Ag & $\mathrm{Pb}$ & $\mathrm{Ni}$ & $\mathrm{Sb}$ & $\mathrm{Cu}$ & $\mathrm{Zn}$ \\
\hline 1 & A & blade - bishop's crosier & 3 & 88,2 & 9,5 & 2,1 & 0,0 & 0,0 & 0,0 & 0,0 & 0,0 & 81,8 & 18,2 \\
\hline 2 & A & blade - unicorn & 3 & 70,4 & 23,9 & 5,7 & 0,0 & 0,0 & 0,0 & 0,0 & 0,0 & 80,8 & 19,2 \\
\hline 3 & A & blade - rosette & 3 & 99,6 & 0,12 & 0,03 & 0,0 & 0,0 & 0,0 & 0,0 & 0,0 & 81,9 & 18,1 \\
\hline 4 & B & $\begin{array}{l}\text { blade - brass beyond } \\
\text { a mark }\end{array}$ & 3 & 99,6 & 0,13 & 0,04 & 0,0 & 0,0 & 0,0 & 0,0 & 0,0 & 76,6 & 23,4 \\
\hline 5 & B & $\begin{array}{l}\text { crossguard - strip with } \\
\text { engraved decoration }\end{array}$ & 8 & 9,8 & 67,2 & 21,9 & 0,0 & 0,0 & 0,1 & 1,0 & 0,0 & 75,4 & 24,6 \\
\hline 6 & A & $\begin{array}{l}\text { crossguard - strip with } \\
\text { engraved decoration }\end{array}$ & 8 & 4,1 & 70,8 & 24,1 & 0,0 & 0,0 & 0,2 & 1,0 & 0,1 & 74,6 & 25,4 \\
\hline 7 & B & $\begin{array}{l}\text { crossguard - decoration } \\
\text { of the écusson }\end{array}$ & 8 & 0,4 & 38,7 & 13,0 & 46,7 & 0,0 & 0,3 & 0,6 & 0,1 & 74,9 & 25,1 \\
\hline 8 & A & $\begin{array}{l}\text { crossguard - decoration } \\
\text { of the écusson }\end{array}$ & 8 & 0,3 & 55,6 & 16,4 & 26,2 & 0,2 & 0,3 & 0,7 & 0,1 & 77,2 & 22,8 \\
\hline 9 & A & $\begin{array}{l}\text { crossguard - lion } \\
\text { mascaron }\end{array}$ & 8 & 0,6 & 53,5 & 15,1 & 29,1 & 0,2 & 0,5 & 0,6 & 0,1 & 78,0 & 22,0 \\
\hline 10 & B & $\begin{array}{l}\text { crossguard - lion } \\
\text { mascaron }\end{array}$ & 8 & 0,1 & 58,7 & 18,2 & 21,8 & 0,0 & 0,3 & 0,7 & 0,1 & 76,4 & 23,6 \\
\hline 11 & B & crossguard - dragon & 3 & 0,6 & 73,4 & 24,7 & 0,0 & 0,0 & 0,2 & 1,1 & 0,1 & 74,8 & 25,2 \\
\hline 12 & B & crossguard - dragon & 3 & 1,5 & 71,4 & 25,6 & 0,0 & 0,0 & 0,6 & 0,7 & 0,1 & 73,6 & 26,4 \\
\hline 13 & A & $\begin{array}{l}\text { grip - lining of the } \\
\text { grip openings }\end{array}$ & 3 & 1,4 & 71,2 & 25,0 & 0,0 & 0,0 & 1,4 & 1,0 & 0,0 & 74,0 & 26,0 \\
\hline 14 & A & grip - nail & 3 & 2,2 & 60,8 & 33,6 & 0,0 & 0,0 & 3,4 & 0,0 & 0,0 & 64,4 & 35,6 \\
\hline 15 & A & $\begin{array}{l}\text { tang - braze alloy } \\
\text { attaching the screw }\end{array}$ & 8 & 48,3 & 41,2 & 10,3 & 0,0 & 0,0 & 0,0 & 0,1 & 0,0 & 79,9 & 20,1 \\
\hline 16 & - & $\begin{array}{l}\text { pommel - braze alloy } \\
\text { of the barrel nut }\end{array}$ & 3 & 51,8 & 48,2 & 0,0 & 0,0 & 0,0 & 0,0 & 0,0 & 0,0 & 100,0 & 0,0 \\
\hline 17 & - & pommel - bear & 8 & 12,0 & 68,1 & 18,6 & 0,0 & 0,0 & 0,2 & 1,0 & 0,0 & 78,5 & 21,5 \\
\hline 18 & - & pommel - dragon & 8 & 0,1 & 73,5 & 25,1 & 0,0 & 0,0 & 0,2 & 1,0 & 0,1 & 74,5 & 25,5 \\
\hline
\end{tabular}




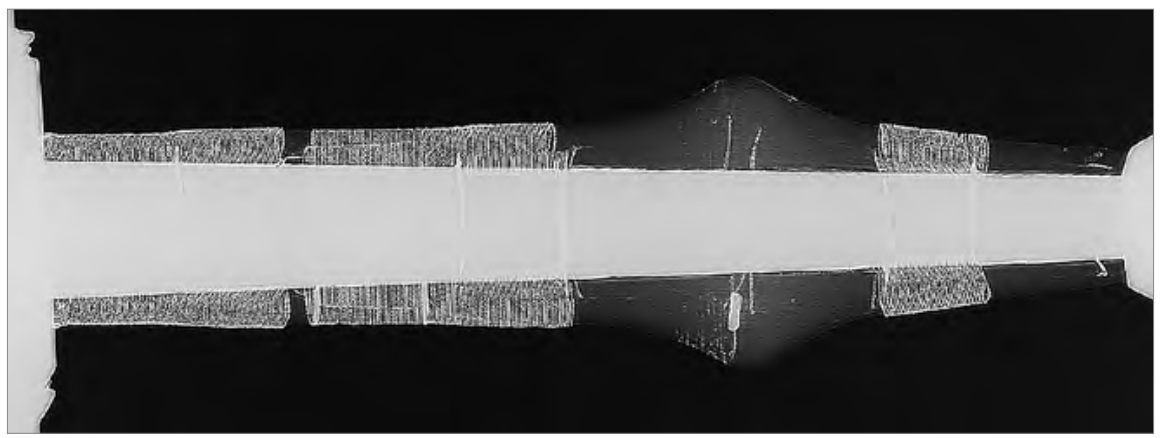

Fig. 8. X-ray image of the grip revealing details of the grip construction. Photo by P.Žákovský.

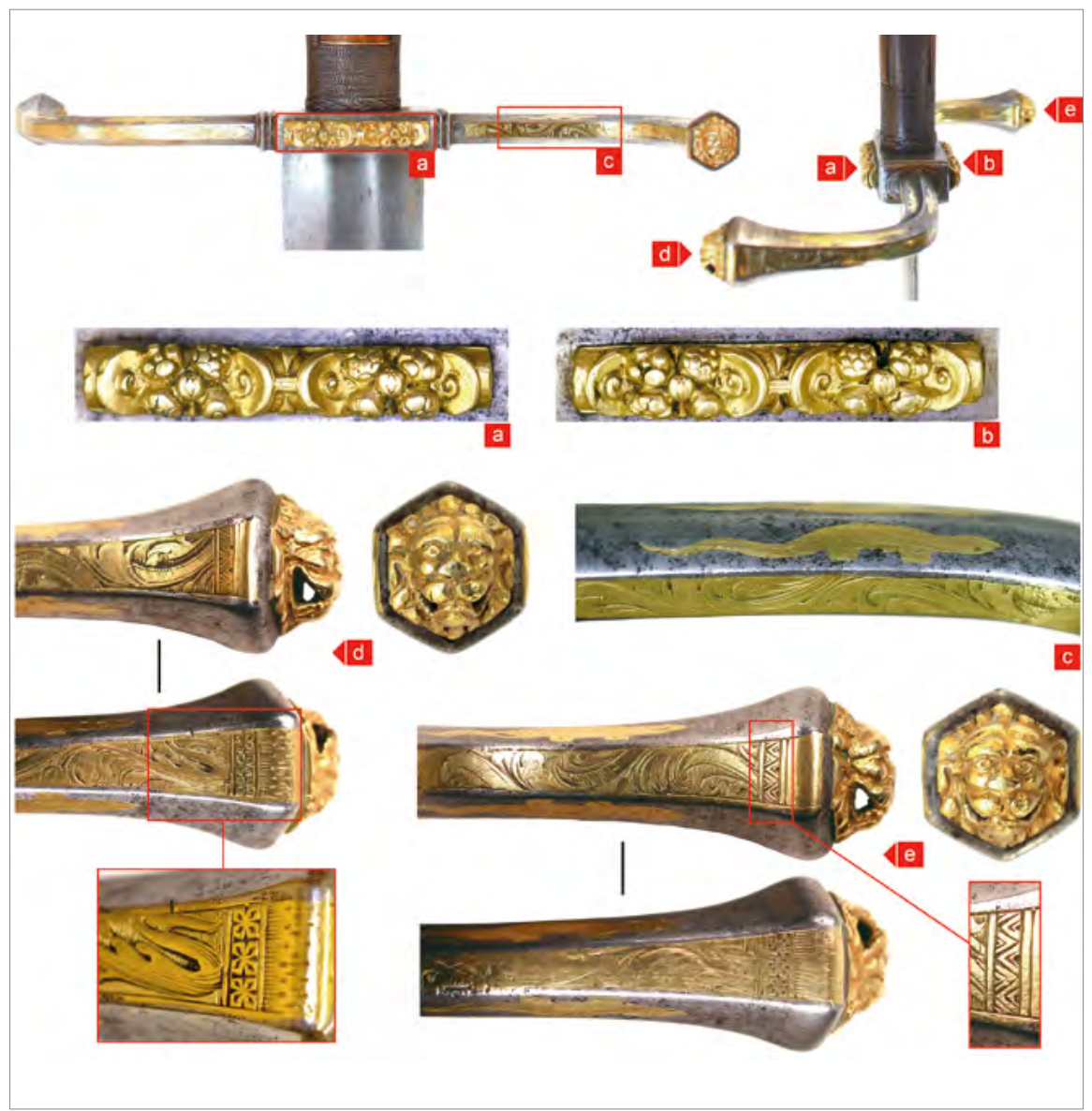

Fig. 9. The crossguard and details of the applied decoration. Photo by P.Žákovský. 


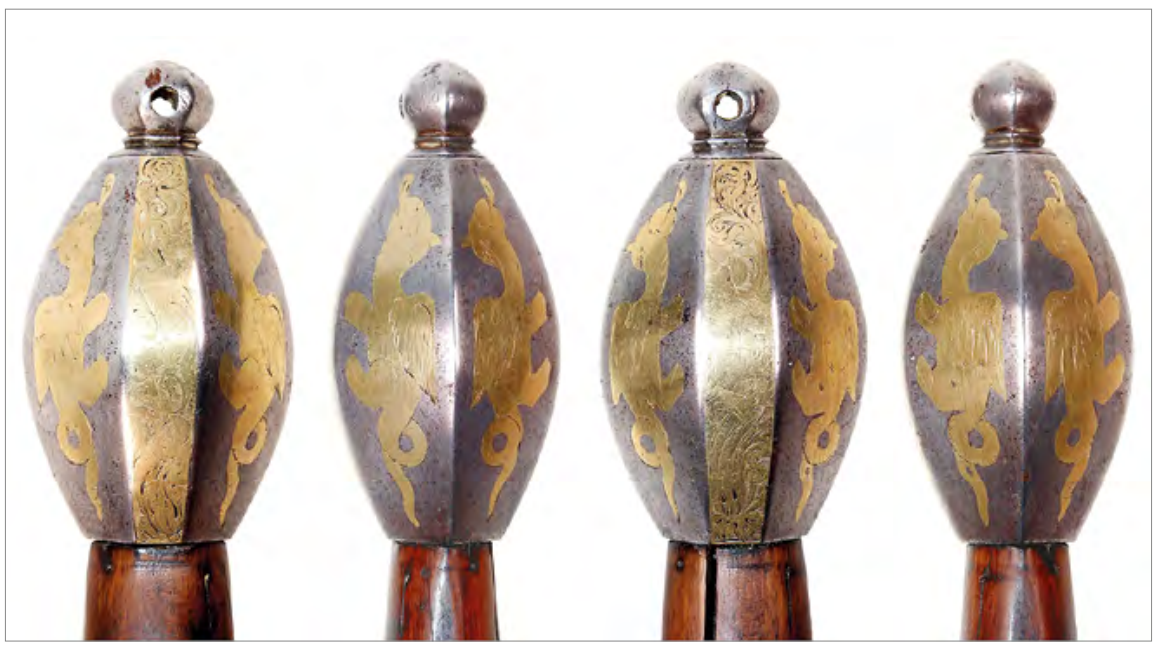

Fig. 10. The pommel from different views. Photo by P.Žákovský.

grooves is typical for this technique (e.g., Žákovský et al. 2020: 374-375, fig. I3). The correct identification of this decorative technique is also supported by the accidentally filled depression on the blade, which is not a part of any signature but the result of the poorly executed forge-welding of the blade. Altogether, the process of inlaying the maker's marks cannot be considered successful in this case, as most of the grooves forming the signatures remained empty. The tang of the blade is roughly $310 \mathrm{~mm}$ long but its other dimensions could not be determined because it is almost completely hidden inside the grip. The grip is made of wood, is approximately $217 \mathrm{~mm}$ long and relatively intricately profiled. In the mid-point of its length, the grip is extended into a distinctive irregular ring decorated with nails of iron and one of brass. The brass nail differs in composition from other brass components and decorative elements of the hilt (Tab. I) by a significantly higher zinc and lead content and the absence of nickel and antimony. The grip could therefore be provided with this nail, and perhaps also with those of iron, later. The dimensions of the grip were measured just above the crossguard, in the widest part of the extended ring and just below the pommel. The width of the grip in these places reaches 36,54 and $24 \mathrm{~mm}$ and the thickness 23,45 and $19 \mathrm{~mm}$, respectively. Since the grip could not be taken off of the tang, its exact construction, which was not clarified even by X-ray radiography, remains unclear. The wooden part was probably made in a standard manner, i.e., from two halves, both hollowed-out on one side to fit the tang and then glued together.

Part of the grip is wound with twisted iron wires from which a decorative turban was also made just above the crossguard. The grip is provided with square and 


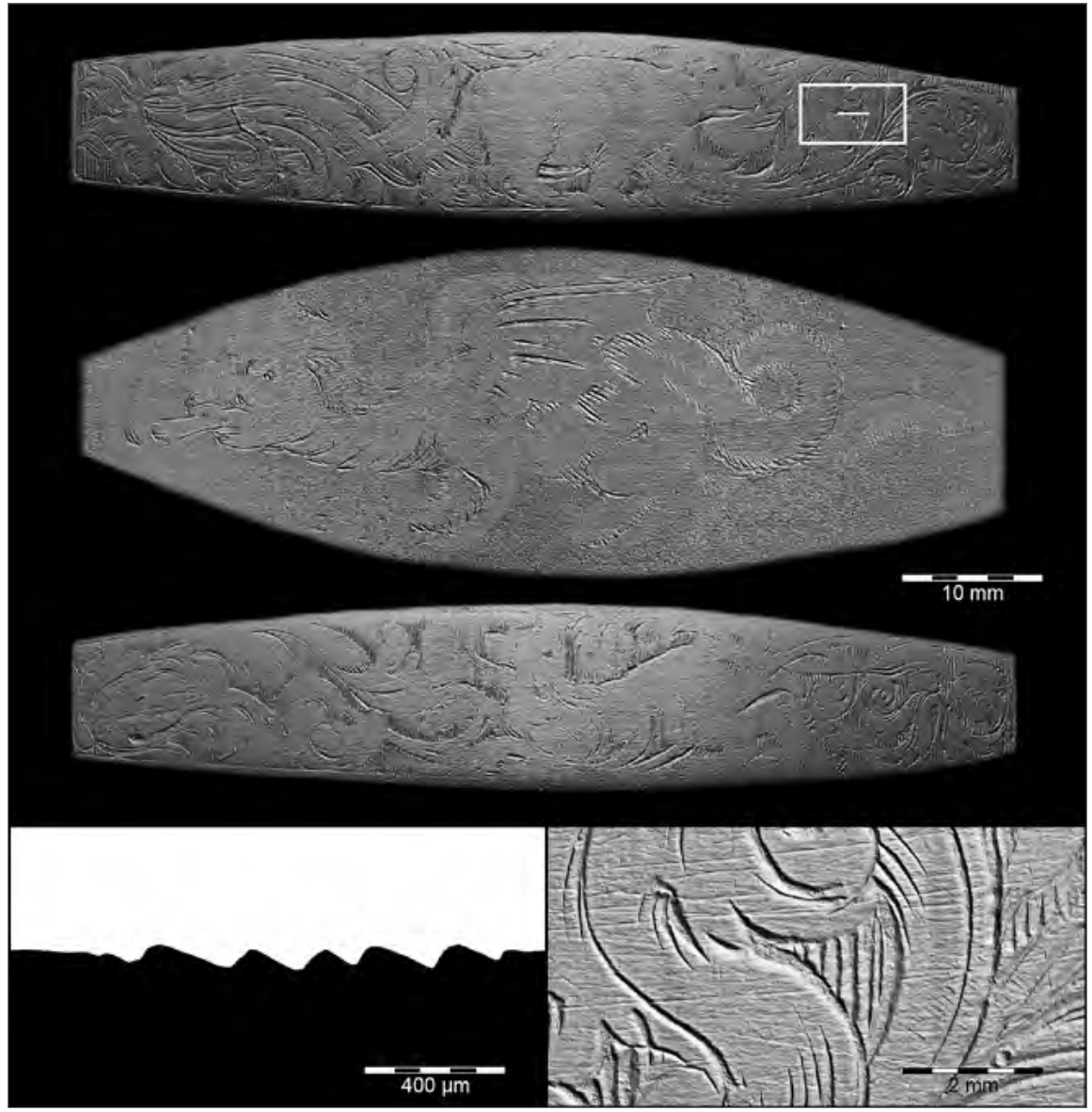

Fig.11. Details of inlaid strips and a figure of a dragon on the pommel, including a virtual cross-section through the engraved surface. Photo by M. Kmošek.

rectangular openings, the upper and lower sides of which are lined with inserts of brass having a similar composition as the inlays and the cast components of the hilt, including comparable content of both zinc and admixtures (Tab. I). The openings contain wooden inserts with a roughly treated surface, which contrasts with a very well-crafted grip as a whole. These inserts are presumably the result of some restoration treatment performed in the past rather than genuine components. Most likely, the openings were originally windows through which the tang of the weapon was visible, as one can see on analogous swords from the collections of the National Museum in Prague (Hošek et al. 2019: cat. ID No 368, tab. Xv: b), National Museum in Kraków (Trzciński 200I: 49, fig. II.20), the National Museum in Kielce (Trzciński 2001: 94-95, fig. II.60) and the Kunsthistorisches 


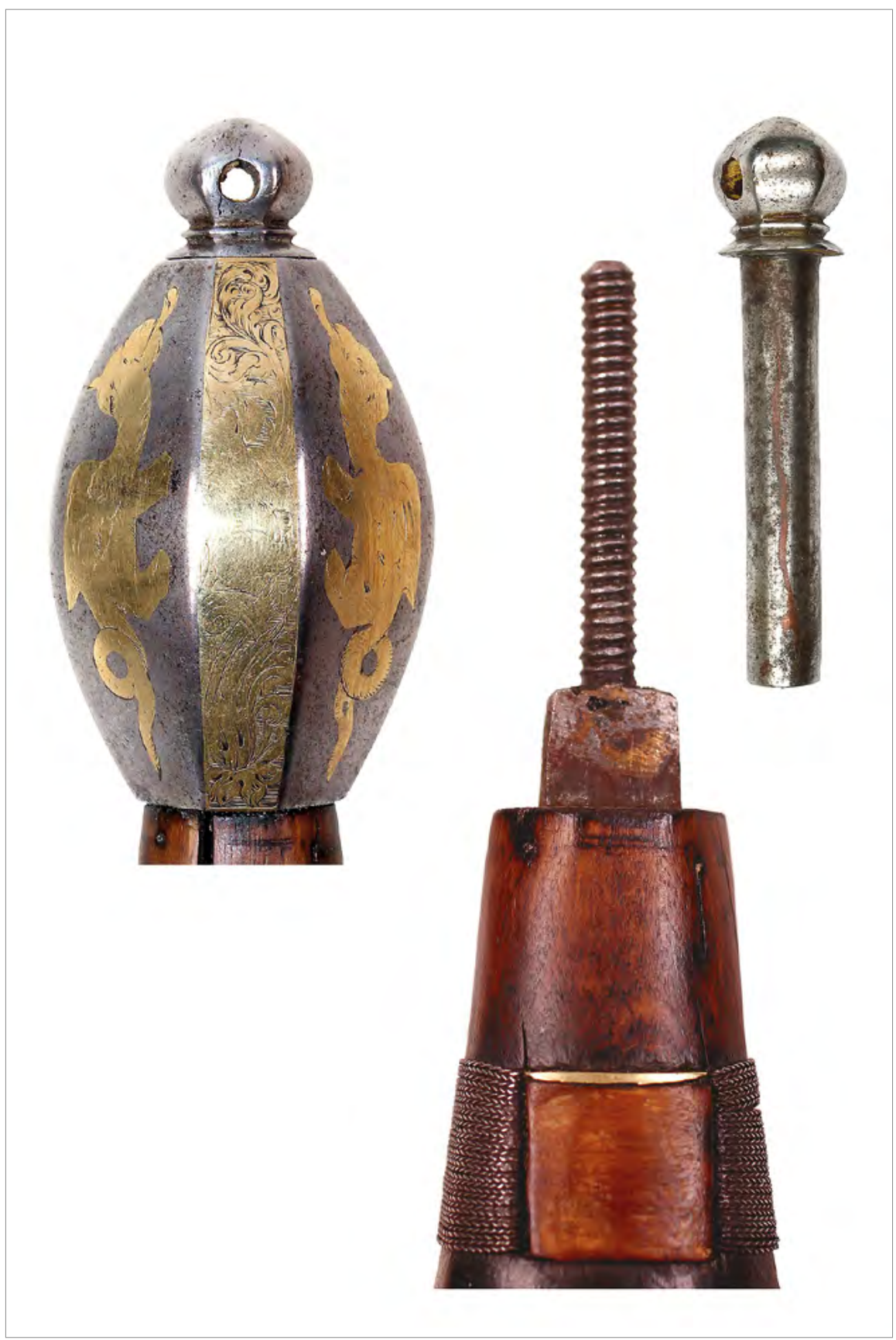

Fig.12. Disassembled topmost part of the hilt showing specific construction for fastening the pommel to the tang. Photo by P.Žákovský. 


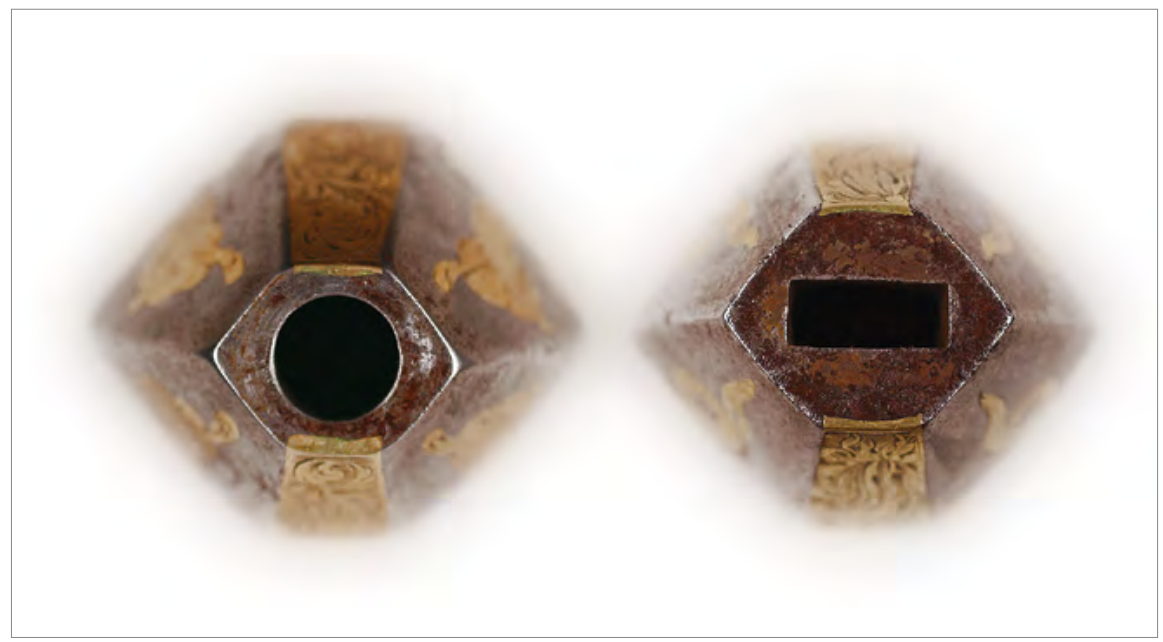

Fig.13. Detail of the topmost and the bottom side of the pommel with holes corresponding to the barrel-nut and the tang profile, respectively. In addition, inlaid strips of brass with engraved decoration are also clearly visible. Photo by P. Žákovský.

Museum in Vienna (Leitner 1866-1870: 2, tab. II: 3). The tang of the Buchlov sword thus had to be surface-treated as carefully as the blade. This is not contradicted by an X-radiogram (Fig. 8), which reveals its geometrically accurate form without traces of hammer blows, which are otherwise commonly encountered on the majority of sword tangs.

The horizontally S-shaped crossguard is $291 \mathrm{~mm}$ long, the quillons are hexagonal in cross-section and they continuously widen towards their terminals from I 2 to $24 \mathrm{~mm}$. The distinctively profiled écusson is $24 \mathrm{~mm}$ wide and $36 \mathrm{~mm}$ thick. The whole crossguard is richly decorated with inlaid bands of brass with engraved plant patterns, and by sixteen inlaid figures of dragons, salamanders or basilisks. Both of the quillon terminals are decorated with an insert in the form of a lion mascaron, and both the front and back side of the écusson have an insert showing two groups of five roses in relief. From a technological point of view, the decoration of the crossguard is made of two types of inlays. The écusson and terminals of the quillons bear a total of four gilded-brass ${ }^{5}$ inserts richly decorated in relief;

5 The hilt components cast of brass and gilded were most likely gilded with golden amalgam (Tab. I). However, the presence of mercury, which safely demonstrates this technology, is not measurable by the handheld spectrometer used due to the absence of the appropriate calibration, so that the gilding technology can be derived only indirectly. The brass of the cast components is similar to those used for the aforementioned inlaid parts or maker's marks. The brass has a similar content of both zinc and admixtures, but the detected 
(Tab. I). These were inserted into the pre-prepared hollows and fixed by tamping the edges of the hollows with a suitable tool so that the cast decor of the inserts was not damaged. The second type of inlays are flat, roughly I $\mathrm{mm}$ thick inserts of brass ${ }^{6}$ applied as strips or taking the form of various creatures (see Tab. I). The individual decorative elements were set into the prepared hollows by hammering the inserts in and, afterwards, smoothed and engraved by common burins. Although the engraved motifs are heavily worn off in many places, the engraving was obviously of a high quality.

The pommel is hexagonal in cross-section and $69 \mathrm{~mm}$ long. At its lower edge, at the mid-point of its length and at the upper edge it is 26,48 and $\mathrm{I} 8 \mathrm{~mm}$ wide and 22,42 and $22 \mathrm{~mm}$ thick, respectively. The surface of the pommel is richly decorated with four large inlays in the form of dragons (or salamanders or basilisks), which are separated on both the front and back side by strips with engraved decoration in the form of plant patterns with a central figure of a bear on one side and a lion on the other. Besides the rich decoration, the pommel is also interesting for its relatively original way of attachment to the weapon. At the end of the conically tapering tang, an additional T-shaped component was brazed (Tab. I) and its longer arm provided with a thread for fixing the pommel. The resulting bolt has a diameter of 6.I $\mathrm{mm}$ and the thread itself has a pitch of $1.5 \mathrm{~mm}$ per revolution. In terms of shape, the thread is comparable with today's round thread, i.e., the thread has an approximately sinusoidal profile in the longitudinal section. The bolt formed at the end of the tang fits a barrel nut headed with a hexagonal knob resting on the pommel of the weapon when assembled. When manufacturing this component, a flat strip was probably forged from a lower part of the knob and subsequently rolled up into a tube, the seam of which was brazed with copper (Tab. I) analogous to the constructions of tubular shanks of keys commonly encountered from the $14^{\text {th }}$ to the $19^{\text {th }}$ century. A thread corresponding to the bolt on the tang was then cut into this tube with a tap. The pommel, fastened by this knob, is partially hollow; the cavity is irregular and roughly copies the outer shape of the pommel with a wall thickness of about $10 \mathrm{~mm}$. We then see at the bottom of the pommel a rectangular hole for the end of the tang and at the top a circular

traces of silver and slightly increased lead content are presumably related to the gilding process/composition of golden amalgam.

6 The inlaid areas on the crossguard and pommel as well as the preserved inlays of the marks on the blade are of brass with a zinc content in the range of 18 to $26 \%$. This zinc content is also detectable in places with a minimum amount of the inlaying metal, or even without its visible traces in the recess of the marks on the blade (Tab. I, measurements nos. 3 and 4). In addition to copper and zinc, the brass also contains admixtures of nickel, lead and antimony. 
hole with a diameter corresponding to the outer dimension of the barrel nut. This way of fastening a sword pommel, uncommon at the time, must be considered genuine and its advantage is that the end of the tang does not need to be peened over a washer or even directly the top of a richly decorated pommel, as this could damage the pommel decoration. It should be noted, however, that this way of fastening is weaker compared to those based on peening the end of the tang and therefore indicates the ceremonial function of the sword, whose construction was in some details subordinated to the intended decorative program.

\section{Typo-chronological classification of the sword}

The sword is equipped with a relatively indistinctly profiled blade with a shallow and indistinctly oulined fuller, which probably begins at the blade and runs approximately halfway down its length. In its character, the blade corresponds to the Oakeshott Type XIIIa specimens typical especially for $\mathrm{I}^{\text {th }}{ }^{\text {-century long- }}$ swords but also sporadically appearing at the end of the $15^{\text {th }}$ century mainly on magistrates' (court) swords to which the studied weapon can be reliably assigned (Oakeshott 1964: 42-47; Hošek et al. 2020). The horizontally s-shaped crossguard can be assigned to a group characteristic of the second half of the $15^{\text {th }}$ and the first decade of the $16^{\text {th }}$ century, and can be classified as Type I2a (e.g., Oakeshott 1964: II8-I20; Hošek et al. 2020). The pommel can be assigned to a very diverse group of Type $\mathrm{T}$ pommels, which were used on swords especially during the $15^{\text {th }}$ and the first half of the $16^{\text {th }}$ century (Oakeshott 1964: 105-106).

Hence, the weapon can be classified as a Type XIIIa, Tiz, I2a long-sword and assigned to a very specific though small group of richly decorated specimens, which by their character, unusual construction and almost identical decorative program clearly indicate their manufacture within one production centre or directly in one production workshop during a relatively short period of time. For the time being, we know these swords, besides the specimen from Buchlov, from the collections of the National Museum in Prague (Hošek et al. 2019: 344-345, cat. ID No 368, tab. XV: b), Kunsthistorisches Museum in Vienna (Leitner 1866-1870: 2, Table II: 3), National Museum in Kraków (Bocheński 1937: 48, Fig. 2; Swaryczewski 1982: 42-43, Fig. 105; Trzciński 200I: 49, Fig. II.20), National Museum in Kielce (Trzciński 200I: 94-95, cat.

no. 5) and the Museum of the City of Głogów (Trzciński 200I: 92-94, cat. no. 4). Several such swords, now missing, were also held at the former Museum für Kunstgewerbe und Altertümer in Wrocław (Hellmich, Seger 1934: 298-299; Trzciński 2001: 103-105, 108-109, cat. no. 11, 13, 17). This group of weapons is characterised by the special construction of their grips with typical openings through which one can see the iron tang surface as well as by the shape of both 
the pommel and horizontally S-shaped crossguard ${ }^{7}$. They also do not differ much from each other in the types of blades, which are relatively massive, have a lenticular cross-section and their fullers run either halfway or at most onethird of the way down the blade length. These swords are probably united also by a very specific and unusual way of fastening their pommels by a barrel-nut component screwed onto a tang.

However, typical for this group of weapons is primarily their identical decorative program, which differs in details for individual weapons but the basic concept remains the same. On the crossguards, we encounter ribbons with engraved plant-patterned decoration, small figures of dragons and gilded mascarons of lions, in the mouths of which even small rings could have been inserted. One such ring is preserved on the crossguard of the sword from Świdnica (Trzciński 2001: 94-95). As far we can judge on the basis of available documentation, these mascarons appear on all the swords of this group. At the same time, all crossguards of these weapons bear ribbons with engraved decoration in the form of an indeterminate plant pattern terminated with geometric patterns. However, the concept of decoration on individual weapons somewhat differs in details, especially in the depiction of specific tendrils and leaves. Figures of small dragons also appear on almost all crossguards; they are only absent on the specimen from Świdnica. Larger differences were observed in the decoration of individual écussons. All of them are decorated with inserts showing decoration in relief and at least in the case of the Buchlov sword the inserts were gilded. Again, most of them are decorated with plant patterns based on motifs of roses in combination with various leaves, flowers or cones. In the case of the sword from the collections of the National Museum in Prague, this floral motif surrounds the central scene - a male bust in a laurel frame, which probably refers to one of the Roman emperors (Hošek et al. 2019: tab. Xv:b).

As it seems that there are no swords with identical écusson decorations, the inserts were cast for each specimen individually. The decoration of pommels also differs in details but is united by the use of relatively large figures of dragons. On the Buchlov sword, these dragons are combined with ribbons showing engraved plant-patterned decoration and figures of a bear and a lion (Fig. II), which has a certain parallel in the pommel of a sword from Kraków (Trzciński 200I: fig. II.20). Unique decoration is found on the pommel of the sword held in collections of the National Museum in Prague; figures of dragons are, on other surfaces of the pommel, accompanied by decorations in the form of pomegranates surrounding lion mascarons with rings in their mouths (Hošek et al. 2019: tab. Xv:b).

7 There are also several crossguards with straight quillons with significantly extended terminals on which lion mascarons are presumably applied (Trzciński 2001: 103, 108-109, cat. no. II, 17). 
The only sword that significantly differs from this group is the one from the collections of the Kunsthistorisches Museum in Vienna, whose pommel is somewhat differently shaped ${ }^{8}$. However, even this pommel, which is circular in cross-section and can best be likened to the pommels of later rapiers of Norman Type 26 (Norman 1980: 25I), is decorated with inlaid or gilded applications, based on decorative motifs, which are characteristic of the studied group of swords. At the lower base of the pommel is a band with engraved decoration in the form of an acanthus pattern. Similar bands, vertically situated, visually divide the pommel into two halves, of which both are provided with a figure of a pair of dragons that are fully analogous to those we encounter on crossguards of swords from the studied group, including the one from Vienna.

Concerning the possible symbolic meaning of the decorative program of these swords, we can state that there is no connection with the primary Christian symbolism usually encountered on medieval swords. The decoration is dominated by a lion and dragon motif, in the Buchlov case supplemented by a motif of a bear. The lion was also a personification of strength and power in Christian symbolism, and in a figurative sense, it could also be a symbol of Christ (e.g., Royt, Šedinová 1998: 147-I 48; Heinz-Mohr 1999: 133-135). On the other hand, the bear was perceived rather negatively in Christian symbolism as a personification of dark forces. However, its certain characteristics, such as the ability to learn and to submit to human captivity, were perceived positively (e.g., Royt, Šedinová 1998: I49-I50; Heinz-Mohr 1999: I55-I56), which is certainly of some significance with regard to the presumed function of a sword. The symbolic meaning of a dragon in medieval iconography is rather complicated. Despite an undoubted negative ideological framework, the dragon could also be a symbol of courage, protection, etc. (e.g., Koutský 2005: 94-95, I3I). Very often, in the same way as the motif of a lion', dragons were in various forms a part of the decoration of medieval arms and armour, where they undoubtedly fulfilled an apotropaic function (e.g., Marek 2017: 78; Michalak 2018: 164-166). However, a dragon could also be a transferred symbol of the fight against evil (e.g., Heinz-Mohr 1999: 50-52) and again in the connotation with the assumed primary function of the studied weapon, this meaning could be, to an increased extent, intentionally visualised on the sword and in this form probably generally understood.

8 A certain parallel is perhaps the pommel of one of today's missing swords from the collections of the Wrocław Museum (Trzciński 200I: 103-104, cat. no. II).

9 The figures of a lion and a dragon are not unequivocally opposing each other on any sword from the studied group, or at least none of such scenes can be interpreted as a fight between these two beasts, i.e., as the motif often encountered in medieval art and having a deeper symbolic meaning (e.g., Réthelyi 200r). 
Certain differences can also be seen in the technology of making the decorative elements of individual weapons, indicating that manufacturers (or a manufacturer) of this group of swords were (or was) looking for the most efficient way for their production and decoration. This can be demonstrated mainly in the technique of making dragon figures on the pommel of the sword from Buchlov and the sword from the collections of the National Museum in Prague. While dragons of the Buchlov sword are inlaid, dragons of the 'Prague' sword are undoubtedly engraved and gilded (cf. Hošek et al. 2019: tab. XV).

The sword from the collections of the Buchlov State Castle can thus be unambiguously assigned to a specific group of luxurious ceremonial weapons whose mutual similarity, despite minor individual differences, proves that even such products, seemingly completely subordinated to the individual taste and needs of customers, could be produced in larger series. At the same time, their undoubted affinity refers to a shared origin. But where to seek the production centre in which these luxury weapons were made, and how to classify them chronologically? There is no simple and definitive answer to these questions, partly because, for the time being, we have information on only a limited number of these weapons, which, moreover, are in many cases missing nowadays and hence unavailable for more detailed investigation.

If we focus on the question of their dating, based on a typo-chronological analysis we can say that these swords were most likely produced sometime at the turn of the $16^{\text {th }}$ century. Polish scholar M. Trzciński dated some of these swords, known to him from Silesia, to the $17^{\text {th }}$ to mid-I $8^{\text {th }}$ centuries (Trzciński 200I: 92-95). Nevertheless, he undoubtedly based such a late dating on the etched inscriptions seen on one of these swords, mentioning also the year 1736 when its blade was provided with the decoration. However, we believe that the inscription was etched to the blade as a later modification. We thus lean towards the dating proposed by Q. Leitner more than a century ago when he studied the famous Viennese armoury. By the way, Leitner assumed that the sword from the Viennese armoury was provided with an older blade (Leitner 1866-1870: 2); such a hypothesis cannot be completely rejected, but we consider it unlikely. To conclude, we believe that the given group of swords should be dated to the end of the $15^{\text {th }}$ and the early (or rather first decades) of the $16^{\text {th }}$ century.

If we accept the proposed dating, we still have to make a few remarks about the possible origin of the swords. Of course, one cannot rule out the possibility that some of these swords may have been fitted with imported blades and can thus be the result of the production of two independent and remote workshops, which was already quite common practice in the High and Late Middle Ages. However, in the case of such a specific group of weapons, this possibility seems unlikely to us. We therefore believe that these swords, unless they were later modified over time, 
are the output of one production centre. Based on the data obtained so far, we can seek this centre in famous Bavarian Passau. This assumption is also supported by the fact that three swords from this group are signed on their blades with marks that can be associated with Passau workshops. The Viennese armoury specimen bear marks in the form of a rosette, a bishop's crosier and a third no longer identifiable mark (Leitner I866-I870: tab. II: 3). One of the swords missing today from Wrockaw bore three marks in the form of a running wolf, an imperial orb and an eight-pointed star in a circle (Hellmich, Seger 1934: 298, fig. 2; Trzciński 200I: IO3-IO4, cat. no. II). This specific combination of marks may perhaps even point directly to the workshop of the Passau branch of the Standler swordsmith family (e.g., Źákovský 2008: 483-485). Finally, the Buchlov sword bears a combination of marks in the form of a trinity of rosettes, a unicorn and a bishop's crosier (Fig. 4). Other hitherto known swords from the studied group either lack maker's marks or are signed with unclassifiable marks (Hellmich, Seger 1934: 298, fig. 4).

Despite both the relatively limited source base and various individual differences in the complex constructions of the grips as well as the techniques of making individual decorative elements, we believe that the origin of this group of swords is common and can be traced to one of Passau's workshops. In our opinion, the question of provenance may also be closely connected to the interpretation of these swords; they can be interpreted as court or magistrates' swords, the function of which we will briefly mention at the end of this study. In any case, with regards to the symbolic and ceremonial function of these swords, their manufacturers obviously paid maximum attention to their production. These have always been elaborately crafted items, often with a very complex and original grip and a richly signed blade ${ }^{10}$. It is therefore not surprising that sometimes the making of a magistrate's sword is mentioned even as a part of a master exam within a swordsmith's guild, as we have evidenced, for example, by the guild statutes from 1497 in Poznań, Poland (Maisel 1961: 280; Trzciński 200I: 65). Although these generally luxury swords could be produced by local workshops, based on the preserved material from Czech territory we believe that representatives of individual towns and cities ordered these weapons mostly from famous production centres of the period. This act in itself should undoubtedly increase the prestige of the authorities and at the same time visualise the economic and cultural level of the town. If we look at the material registered so far from the Czech Republic, it reflects a certain close connection to the production centre in Passau, Bavaria; such a connection can

10 In this respect, we cannot accept M. Trzciński's statement that the majority of court i.e., magistrates' swords were not signed and, therefore, their production by local workshops should be considered (Trzciński 200r: 7I). The material recorded so far from the territory of the Czech Republic clearly speaks against this assumption. 
generally also be observed in the massive import of battle swords or their blades during the $14^{\text {th }}$ to mid- $\mathrm{I}^{\text {th }}{ }^{\text {th }}$ centuries ${ }^{11}$ (Hošek et al. 2020).

For the time being, a total of 14 swords from the $14^{\text {th }}$ to mid- $16^{\text {th }}$ century documented in Czech collections can be interpreted with a greater or lesser degree of probability as magistrates' (or court) swords ${ }^{12}$ (see Hošek et al. 2019: cat. ID Nos 38 , $55,166,284,285,286,288,312,315,362,368,409,426,427)$. The vast majority of these swords bear a mark in the form of the so-called Passau wolf or unicorn (Hošek et al. 2019: cat. ID Nos 38, 284, 285, 286, 288, 312, 315, 362, 409), a bishop's crosier (Hošek at al. 2019: cat. ID Nos 166, 426, 427), or a combination of these specific signatures (Hošek et al. 2019: cat. ID Nos 288, 362), which is also the case of the sword from Buchlov. These marks may then be accompanied by other signatures that can be considered as makers' marks of individual manufacturers. Some such signatures documented on swords from the Czech territory have the form of an imperial orb, which in combination with the so-called Passau wolf can indicate the origin of these weapons in the workshops of the Passau swordsmith's family of Standler (Hošek et al. 2019: cat. ID Nos 284, 285, 362). In rare cases, they take the form of a rosette (Hošek et al. 2019: cat. ID No 288) or star (Hošek et al. 2019: cat. ID No 312). More frequently we also encounter various types of crosses (Hošek et al. 2019: cat. ID Nos 166, 285, 312, 409) or a divided circle (Hošek et al. 2019: cat. ID Nos 284,315$)$. Only rarely are the signatures accompanied by inscriptions. In

11 Of the 125 obviously marked blades of $\mathrm{I} 4^{\text {th }}$ - to mid- $16^{\text {th }}$-century swords from Czech territory, 59 specimens (i.e., $45 \%$ ) are signed with marks that can most likely be associated with the Passau production centre. If we omit 16 swords with marks that can no longer be interpreted due to their poor state of preservation, this percentage (45\%) would rise to $54 \%$ (Hošek et al. 2020).

12 However, this list does not claim to be complete; there are a number of specimens that we could not, for various reasons, document in greater detail when making the inventory. These include, for example, a luxurious magistrate's sword of the town of Olomouc from the I540s, in whose production and decoration the local goldsmith Asver Fidler was also probably involved (e.g., Čermák 1999: 560, cat. no 475) and a beautiful sword from the turn of the $16^{\text {th }}$ century, which probably served as the ceremonial sword of the České Budějovice mayor, with a hilt completely covered with leather, including a pear-shaped pommel and crossguard. The whole situation is further aggravated by the fact that many of these ceremonial swords are not yet in official museum collections but held at city halls as reminders of their former jurisdiction (e.g., Konečný 2007: 88). Many of them thus escaped our attention, as have the magistrates' swords held in official collections, which, due to the morphology of the hilt, are generally dated to the $17^{\text {th }}$ to $18^{\text {th }}$ century, thus beyond the time horizon of our work. However, when assembling these weapons, older blades symbolising the continuity of the jurisdiction of individual municipalities could also be used for reverential reasons, while the older hilt components were replaced by new ones better fitting the aesthetic aspects of the time. Targeted research on this specific group of swords would undoubtedly bring a number of new discoveries and findings in the future. 
this respect, the inscription on the somewhat oversized sword from the turn of the $16^{\text {th }}$ century held in the collections of the of the City of Prague Museum deserves special attention because it undoubtedly testifies to the original function of this weapon. Its blade is inscribed on both sides, between the marks in the form of the so-called Passau wolf and bishop's crosier, with capital letters "RBI" or "RDI", which we could interpret as the initial abbreviation of the phrase "Regni Bohemiae Iustitia"13 (Hošek et al. 2019: cat. ID No 362).

The fact that the vast majority of magistrates' swords documented so far in Czech collections are signed by makers' marks connected to the Bavarian production centre testifies that Passau products enjoyed a considerable reputation in the Czech Lands ${ }^{14}$. However, the question is whether all these swords were complete products of the Passau masters or only bare blades were exported to be hilted by local craftsmen. Almost all these special swords documented from Czech territory were provided with relatively wide blades, which can be classified as Oakeshott Type XIIIa (Hošek et al. 2019: cat. ID Nos 38, 55, 166, 284, 286, 288, $312,362,368,409$ ) or possibly XIIa (Hošek et al. 2019: cat. ID Nos 285, 315), and in individual cases as late medieval blades of Types XIX (Hošek et al. 2019: cat. ID No 427) and $x x$ (Hošek et al. 2019: cat. ID No 426). Hence, the applied blades are usually archaic in shape, which we already encounter on modern battle swords only sporadically. This could lead us to the idea that most of these blades are

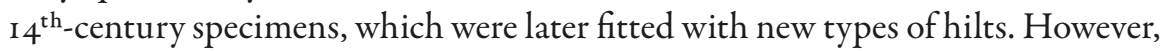
this possibility seems very unlikely. The reason mostly lies in the fact that the archaic-shaped blades were probably the most suitable for ceremonial purposes, as they were relatively long and only slightly narrowing towards the point. As a result, the swords were highly impressive, which was also amplified by the fact that some of them were intentionally oversized.

Based on the above facts, we believe that the studied group of richly and rather uniformly decorated and constructed magistrates' swords was made in a relatively

13 Certain parallels to this blade are represented by two fully intact swords held in the collections of the Hofjagd- und Rüstkammer in Vienna, which, however, are provided with initial inscriptions of probable Christological content (Leitner 1866-I870: 2-3, Pl. II:5, 8; Gamber 196r: 26-27, fig. 18; Thomas, Gamber 1976: 76).

14 Even matistrates' swords marked in this way are sometimes, somewhat paradoxically, considered weapons with counterfeit signatures (e.g., Kühn 1970: 105; Trzciński 2001: 65-67). However, we believe that in the case of magistrates' swords from the turn of the $1^{6^{\text {th }}}$ century, this assumption is unlikely, especially with regard to the nature and purpose of these weapons. In our opinion, there is no reason to doubt the origin of these weapons, or more precisely their blades, in this famous Bavarian production centre, whose production at the turn of the $16^{\text {th }}$ century experienced one of its qualitative and quantitative peaks (e.g., Uhlemann 1982: 33). 
short period of time, sometimes at the turn of the $16^{\text {th }}$ century or probably in the first decades of the century, in Bavarian Passau. The weapons clearly prove that even such products, seemingly completely subordinated to the individual taste and needs of customers, could be produced in larger series, which is not surprising given the number of Central European cities and towns and other authorities with jurisdiction at the turn of the $\mathrm{I}^{\mathrm{th}}$ century.

\section{Interpretation of the sword}

As mentioned above, the weapon held in the collections of Buchlov State Castle can be, thanks to its character and construction, quite unambiguously interpreted as a sword with a special function, which we generally refer to as a magistrates' (or court) swords (so-called Gerichtsschwert). These weapons, like common 'judges' sticks', served as a legal symbol and soon became an attribute of the right to enforce secular law (cf. Fischer 1982). After all, the sword fulfils the role of one of the basic symbols of justice up to now (e.g., Knoll 20ria: 69). The magistrates' swords found their application mainly in the promulgation of the judgment, when, according to a number of written sources, they were to be presented as a symbol of law and jurisdiction either on the judge's bench, or held in the judge's hand or on his lap (Oberpfalcer 1937: 75; Uhlemann 1982: 36-37, fig. I2; Trzciński 2001: 44-5I; Knoll 2orrb: 63). The magistrate's sword also played an important role during court proceedings themselves, especially in the application of the institute of oaths, when all the accused, witnesses and prosecutors were required to swear on the sword (e.g., Uhlemann 1982: 38). Undoubtedly, the sword was to remind the parties to the dispute that perjury was a heinous crime. Magistrates' swords were certainly also presented at various festivities and parades, demonstrating the authority of the representatives of individual towns. These were thus weapons combining both a specific symbolic and representative function, which were inseparable from each other.

However, these weapons did not serve for the actual exercise of capital law, i.e., for the performance of decapitations, as this would be somewhat in conflict with their main symbolic function. Otherwise, these weapons would certainly be considered unclean, just as the other instruments used to enforce capital law. Due to their function, despite being partially modified over time, many of these swords survived for a very long time, and many of them are even in an intact state to this day. The reason is that the magistrates' swords were maintained by individual municipal authorities as one of the most important attributes of their independence and legal competence. Nevertheless, with the modernisation of municipal self-government and the establishment of the mayor's office in 1848 , the importance of these insignia significantly declined (e.g., Večerková 
2010: 13-31; 2015: 57-62) and after the establishment of the museum network in Bohemia and Moravia, most magistrates' swords, no longer used, entered official museum collections.

The studied sword from the collections of Buchlov State Castle can thus be unambiguously assigned to swords with a special, mostly ceremonial and symbolic function. However, whether we can consider it a recollection of the famous hunting law office, which was probably connected with Buchlov Castle since the I $4^{\text {th }}$ century (see, e.g., Dolejšek I893: I8), can no longer be unequivocally certain. We do not have direct written documents on the use of the court sword in trials conducted to enforce hunting law at Buchlov, but given the general practice within the medieval and Early Modern judiciary, it cannot be doubted. Even records of the trials of this court, the so-called Black Books written between 1617 and 1654 but also containing records of older proceedings, do not mention it. We can most likely neither connect the function of a court sword with the 1617 record describing in detail the case of a certain Urban sentenced to decapitation by sword for various thefts of bees and grapes, but finally, this punishment was reduced to expulsion from the domain. However, there was to be a certain symbolic performance of his execution (Verbík 1976: 165) ${ }^{15}$. Here, however, the executioner's sword rather than the court sword was used in this symbolic role, as it is difficult to believe that representatives of the court would lend the attribute of their office for such a purpose because the court sword could then be considered dishonoured and would lose its symbolic value.

\section{Conclusion}

The sword (inv. No. BU 959/290) held in collections of the National Heritage Institute - Buchlov State Castle can be classified as an Oakeshott Type XıIIa, Tı3, I2a long-sword and assigned to a specific group of richly decorated swords united by their overall character, unusual construction and almost identical decorative program indicating their manufacture in the same production centre within a relatively short period of time from the end of the $15^{\text {th }}$ to the first decades of the $16^{\text {th }}$ century. They are characterised by the special construction of their grips with typical rectangular openings and a horizontally S-shape crossguard. At the time, the pommel of the Buchlov sword is attached to the tang in an unusual way by means of a tubular nut screwed onto a bolt brazed to the end of the tang. This technical solution was probably also applied in the case of other similar swords

15 The record literally mentions: ku príkladujiným má mistrpopravčís dobytým mečem nad ním stojice oznámit, že jest pro nenáležitésvé skutky mečem trestán bejti mél... (Verbík 1976: 165). 
from the group. In any case, this group of luxury ceremonial swords, despite minor individual differences, proves that even such luxurious products could be produced in larger series. At the same time, their undoubted kinship refers to their common origin, which - based on their maker's marks - could probably be sought in Passau, Bavaria. The studied sword from the collections of Buchlov State Castle can thus be unambiguously assigned to swords with a special, mostly ceremonial and symbolic, function and can be associated with a group of weapons considered to be an attribute of jurisdiction, so-called magistrates' (or court) swords. However, whether we can consider it in relation to the famous hunting law office that was probably connected with Buchlov Castle since the $\mathrm{I} 4^{\text {th }}$ century (see, e.g., Dolejšek I893: I8) can no longer be decided.

This study was created with institutional support Rvo: 68081758 - The Czech Academy of Sciences, Institute of Archaeology, Brno, v. v. i.

\section{Bibliography}

Bocheński Z.(1937), Krakowski cech mieczników, Towarzystwo Miłośników Historii i Zabytków Krakowa, Kraków.

Čermák M. (1999), Asver Fidler (?) a dalši, rychtárský mečz Olomouce, [in:] I. Hlobil, M. Perůtka (ed.), Od gotiky k renesanci. Výtvarná kultura Moravy a Slezska I400-I55o. III. Olomoucko, Moravaká galerie; Muzeum umění, Brno-Olomouc, p. 560.

Dolejšek B. (1893), Buchlov. Prưvodce pro navštěvovatele hradu, Uherské Hradiště.

Fischer H. (1982), Stab und Schwert als Gegensatzpaar der Rechtssymbolik, "Forschungen zur Rechtsarchäologie und rechtlichen Volkskunde", 4, p. 3-39.

Gamber O. (196I), Die mittelalterlichen Blankwaffen der Wiener Waffensammlung, "Jahrbuch der Kunsthistorischen Sammlungen", 57, Neue Folge 21, p. 7-38.

Heinz-Mohr G. (1999), Lexikon symbolu. Obrazy a znaky křestanského umèní, Volvox Globator, Praha.

Hellmich M., Seger H. (1934), Die Richtschwerter des Schlesischen Museums für Kunstgewerbe und Altertümer, "Altschlesien", 4, p. 294-30I.

Hošek J., Košta J., Žákovský P. (2019), Ninth to Mid-sixteenth Century Swords from the Czech Republic in their European Context, part I, The Finds, Archeologický ústav AV ČR; Národní muzeum, Masarykova univerzita, Prague-Brno.

Hošek J., Košta J., Žákovský P. (2020), Ninth to Mid-sixteenth Century Swords from the Czech Republic in their European Context, part 2, Swords of Medieval and Early Renaissance Europe as a Technological and Archaeological Sources, Archeologický ústav AV Čr, Národní muzeum, Masarykova univerzita, Prague-Brno.

Knoll V. (20IIa), Krátké zamyšleni nad symbolickým významem a podobou meče soudního a meče katovského, [in:] V. Knoll (ed.), Nadèje právni védy. Býkov 2oro. Sborník z mez- 
inárodniho setkáni mladých vèdeckých pracovnikư konaného ve dnech 23.-25. 4. 2010 na Zámeckém statku Býkov, Vydavatelství a nakladatelství Aleš Čeněk, Plzeň, p. 69-74.

Knoll V. (2oIrb), O katovských mečich, [in:] K. Schelle (ed.), Právni archeologie. Sbornik z mezinárodni védecké konference pořádané Katedrou společenských véd FSv ČVUT $v$ Praze a The European Society for History of Law, Key Publishing, Brno-OstravaPř́íoz, p. 63-68.

Konečný M. (2007), Lomnice za vlády Serényiu (1662-1848), [in:] M. Konečný (ed.), Lomnice. Príroda, historie, osobnosti, památky, Sursum, Tišnov, p. 82-106.

Koutský K. (2005), Draci středověkého světa, Mladá fronta, Praha.

Kühn U.(1970), Das Richtschwert in Bayern, "Waffen- und Kostümkunde", 12, p. 89-126.

Leitner Q. (1866-1870), Die Waffensammlung des österreichischen Kaiserhauses im K. K. Artillerie-Arsenal-Museum in Wien, Verlag von H. Martin, Wien.

Maisel W.(196I), Sądownictwo miasta Poznania do końca XVI wieku, Państwowe Wydawnictwo Naukowe, Poznań.

Marek L. (2017), Średniowieczne uzbrojenie Europy tacińskiej jako Ars Emblematica, Uniwersytet Wrocławski, Wrocław (Wratislavia Antiqua, 22).

Michalak A. (2018), Mystery Hidden behind the Beasts' Heads. Remarks on the Chronology of a Peculiar Type of Medieval Dagger, "Acta Militaria Mediaevalia", I4, p. 153-173.

Norman A.V.B. (1980), The Rapier and Small-Sword, $1460-1820$, Arms and Armour Press; Arno Press, London-Melbourne-New York.

Oakeshott R.E. (1964), The Sword in the Age of Chivalry, Frederick A. Praeger Publishers, London.

Oberpfalcer F. (1937), Vyznáni na mučidlech. Texty ze starých knih černých, jinak smolných, Fr. Borový, Praha.

Prchal V.(2015), Společenstvo hrdinů. Válka a reprezentačni strategie českomoravské aristokracie 1550-I750, Nakladatelství Lidové noviny, Praha (Česká historie, 33).

Procházka R.(1999), Militaria, [in:] K. Chamonikola (ed.), Od gotiky k renesanci. Výtvarná kultura Moravy a Slezska I400-I550. II. Brno, Moravská galerie, Brno, p. 576-58I.

Réthelyi O. (2001), The Lion, the Dragon, and the Knight: an Interdisciplinary Investigation of a Medieval Motif, "Annual of Medieval Studies at the CEU", 7, p. 9-37.

Royt J., Šedinová H. (1998), Slovník symbolu. Kosmos, príroda a člověk v křestanské ikonografii, Mladá fronta, Praha.

Swaryczewski A. (1982), Granat - sztuka mistrzowska stradomskiego cechu mieczników, "Studia do Dziejów Dawnego Uzbrojenia i Ubioru Wojskowego", 8, p. 35-48.

Thomas B., Gamber O. (1976), Katalog der Leibrüstkammer I. Der Zeitraum von soo bis I530, Kunsthistorisches Museum, Verlag Anton Schroll \& Co, Wien.

Trzciński M. (200I), Miecz katowski. Pregierz. Szubienica. Zabytki jurysdykcji karnej na Dolnym Ślasku (XIII-XVIII w.), Uniwersytet Wrocławski, Wrocław.

Uhlemann H.R. (1982), Die mittelalterlichen Gerichtsschwerter und die späteren Richtschwert von Passau, [in:] K. Stüber, H. Wetter (ed.), Blankwaffen. Armi bianche. Edged weapons. Festschrift Hugo Schneider zu seinem 65. Geburtstag, Th. Gut \& co. Verlag, Zürich, p. 33-44.

Večerková E. (2010), Lidové obyčeje a jejich výtvarné komponenty, tvary a symboly, Moravské zemské muzeum, Brno. 
Večerková E. (2015), Obyčeje a slavnosti v české lidové kultuře, Vyšehrad, Praha.

Verbík A. (1976), Črné knihy práva loveckého na hradě Buchlově, Blok, Brno.

Žákovský P. (2008), Značené vrcholně a pozdnè strédověké dloubé meče ze sbirek Mèstského muzea v Broumovè, "Archaeologia historica", 33, p. 471-490.

Žákovský P., Cymbalak T., Hošek J., Dejmal M. (2017), Nález pozdně středověkého dlouhého meče z Prahy - Nového Mèsta, "Přehled výzkumů", 58.2, p. I4I-I87.

Žákovský P., Hošek J., Bárta P., Fojtík A., Popelka M.(2020), Románský mečz Hoštic na Kromérižsku, "Archaeologia historica”, 45.I, p. 363-389, https://doi.org/10.5817/ $\mathrm{AH} 2 \mathrm{O} 20-\mathrm{I}-\mathrm{I} 7$

\section{Streszczenie}

W zbiorach Zamku w Buchlovie znajduje się między innymi bogato zdobiony, późnośredniowieczny miecz długi, który na podstawie jego ogólnego charakteru, w tym znaków wytwórcy na głowni, można wiarygodnie zinterpretować jako tak zwany miecz magistracki wykonany w XVI w. w Passawie w Bawarii. W artykule omówiono charakter jego dekoracji w porównaniu z innymi podobnymi zachowanymi mieczami magistrackimi z Europy Środkowej, pochodzącymi z pracowni w Passawie, a także praktyczną i symboliczną funkcję tej broni.

Słowa kluczowe: miecz magistracki, Passawa, późne średniowiecze, gorąca inkrustacja, wkładka z drutu

\section{Petr Žákovský}

Archeologický ústav AV ČR, Brno

e-mail: zakovsky@arub.cz

\section{Patrick Bárta}

Archeologický ústav AV ČR, Brno

e-mail: barta@arub.cz

\section{Jiří Hošek}

Archeologický ústav AV ČR, Praha

e-mail: hosek@arup.cas.cz

\section{Matěj Kmošek}

Archeologický ústav AV ČR, Brno

e-mail: kmosek@arub.cz 